Article

\title{
Changes in the Dynamics and Nature of Sedimentation in Mill Ponds as an Indicator of Environmental Changes in a Selected Lake Catchment (Chełmińskie Lake District, Poland)
}

\author{
Zbigniew Podgórski and Dawid Szatten * \\ Institute of Geography, Kazimierz Wielki University in Bydgoszcz, Kościeleckich Square 8, \\ 85-033 Bydgoszcz, Poland; zbigniew.podgorski@ukw.edu.pl \\ * Correspondence: szatten@ukw.edu.pl; Tel.: +48-52-349-62-50
}

Received: 10 October 2019; Accepted: 14 January 2020; Published: 17 January 2020

check for updates

\begin{abstract}
The article presents the changes in a hydrographic network resulting from the construction and functioning of nine water mills located in the Struga Rychnowska catchment (Poland). Two ponds (Bierzgieł and Oleszek) have been chosen for a detailed study-both with similar basin origins and morphological settings, but different morphometries, paths of water delivery and discharges from the mill, and water retention times. An attempt was made to restore the course of the deposit sedimentation process in mill pond basins on the basis of historical sources, archived cartographic materials, fieldwork, and laboratory analyses (sedimentology, palynology, and ${ }^{14} \mathrm{C}$ dating). The studies allowed determining the scope of anthropogenic impact on the environment on the example of small river catchment, both when the ponds were in use, and afterwards. Decommissioning of water mills induced a number of serious changes in water resources. The most important of them include: the loss of water retention capacity in the Struga Rychnowska catchment, and decreased ground water level in immediate vicinity of former water reservoirs. Currently, a renewed interest in the old locations of water mills is present, in order to restore retention, and use them for the purposes of modern small hydropower plants (SHP).
\end{abstract}

Keywords: water mills; retention reservoirs (mill ponds); sedimentation; bottom sediments

\section{Introduction}

From the Middle Ages until the 1950s, water mills and their ponds were important elements in the landscapes of small river valleys in Poland [1]. They had an impact on the course of morphological processes, including riverbed processes and water resources in their area. Water mill location is an effect of the relationship between natural conditions prevailing at the time, and socioeconomic conditions [1,2]. The research carried out in Struga Rychnowska catchment can provide results of: the changes in hydrographic network [2,3], the sizes and types of anthropogenic landscape features, and sediments deposited in mill pond basins $[2,4,5]$. They allow determining original condition of geographical environment in the catchment $[2,4,5]$ and the nature of introduced transformations $[1,2,4]$. The analyses of bottom pond sediments are commonly used as indicators of anthropogenic impact on the environment [6-10]. The development of mill ponds could have been the important stimulus of sedimentation in historic times $[6,8,11,12]$. It is also worth noting that the issues of water mill functioning require interdisciplinary studies. The main research fields include: physical and geographical determinants of water mill locations with reference to prehistoric and early medieval settlement $[13,14]$; and the issues of modifications in riverbeds and valley floors in the context of water-driven energy use for economic purposes, as a result of the supply and retention of water for the needs of the 
mills; e.g., construction of dykes, dam, mill trenches, mill channels and bypass channels, basins of dam reservoirs (mill ponds), and levelled surfaces $[1,4,6]$. Research results allow the determination of the courses of morphological processes modified due to the construction and operation of water mills [4,7,15-19]; and determining human interaction with the environment in the context of landscape development, environment protection and sustainable development [20-23], and the impact of land usage and non-agricultural pollution sources in the catchment [24-26]. Scientific papers show that intensive human economic activity based on the use of the energy generated by water mills has caused major changes in the environment [6-10,24].

As regards the Chełmińskie Lake District and the adjacent part of the Pomeranian Lake District, the issue of water mill functioning was taken up by: Niewiarowski [13], Podgórski [27], Podgórski and Luc [28], and Michalska and Szpikowski [17]; however, the environmental changes are not fully presented in these publications. The studies listed above concerned water mill location characteristics, without detailed specifications of form sizes and the dependence of forms on natural predispositions of landscape features and water resources respectively.

The accumulation of sediments in mill reservoirs was characterized by describing changes in the relief associated with the operation of water mills. Only a few publications contain detailed research results in this field [17,29-31]. Several publications concerned the presence of water mills in the landscape-the development of the mill landscape [2,20]. The aim of Mendyk and Sykuła's [32] research was also to assess the spatial variability of real soil moisture, $\mathrm{pH}$, and loose soil electrical conductivity of soil surface levels in a former mill pond.

The authors, aiming to supplement the state of knowledge about the role of water mills in the transformation of the natural environment, have carried out a detailed analysis of their location and the deposited bottom sediments. The main purpose of the study was to determine (using various methods, including bottom sediment analysis collected from mill ponds in selected catchments of the Chełmińskie Lake District) changes in the human-environment relationship as a result of the construction and operation of water mills and the effects of this anthropopressure. In addition, the aim of the research was to determine the character and extent of anthropogenic changes in the relief of the land and surface waters caused by the construction and functioning of watermills. The problem was associated with the intensity of human economic activity, which is reflected in the number of water mills, which is changing in the research area. Studies of this scope have not been carried out previously for the catchment area located in this part of Poland and Europe. However, bottom sediments related to the functioning of water mills were analyzed by other researchers in the context of the role of mill dam in regional erosion and sedimentation [33]. Also, along the middle course of the Havel, sedimentary sequences available for geoarchaeological and paleoecological research were analyzed in order to reconstruct regional water level dynamics [34]. The objective of a study in Germany (Wurm River) and in the Netherlands (Geul River) was to determine how the construction and later removal of water mills had influenced the longitudinal bed profile of a river and its floodplain sedimentation [35]. As presented in that article, a certain research focus is now important, because elimination of water mills induced many serious changes in water resources, including the loss of water retention capacity and decreased ground water level in immediate proximity of water reservoirs. Removal of the mill pound caused higher runoff of the catchment area and the sediment transport process intensified. Currently in Poland, a renewed interest in the old locations of water mills has been observed in the context of restoring the so-called small retention $[2,36]$.

\section{Materials and Methods}

\subsection{Study Area}

The research area covers the Struga Rychnowska River, where 9 water mills were operated altogether in the past (Figure 1). The chronological range of the research was determined by the date of 
installation of the oldest water mill in this area-the 14th century [29], and the date of the field study's completion-the year 2019.

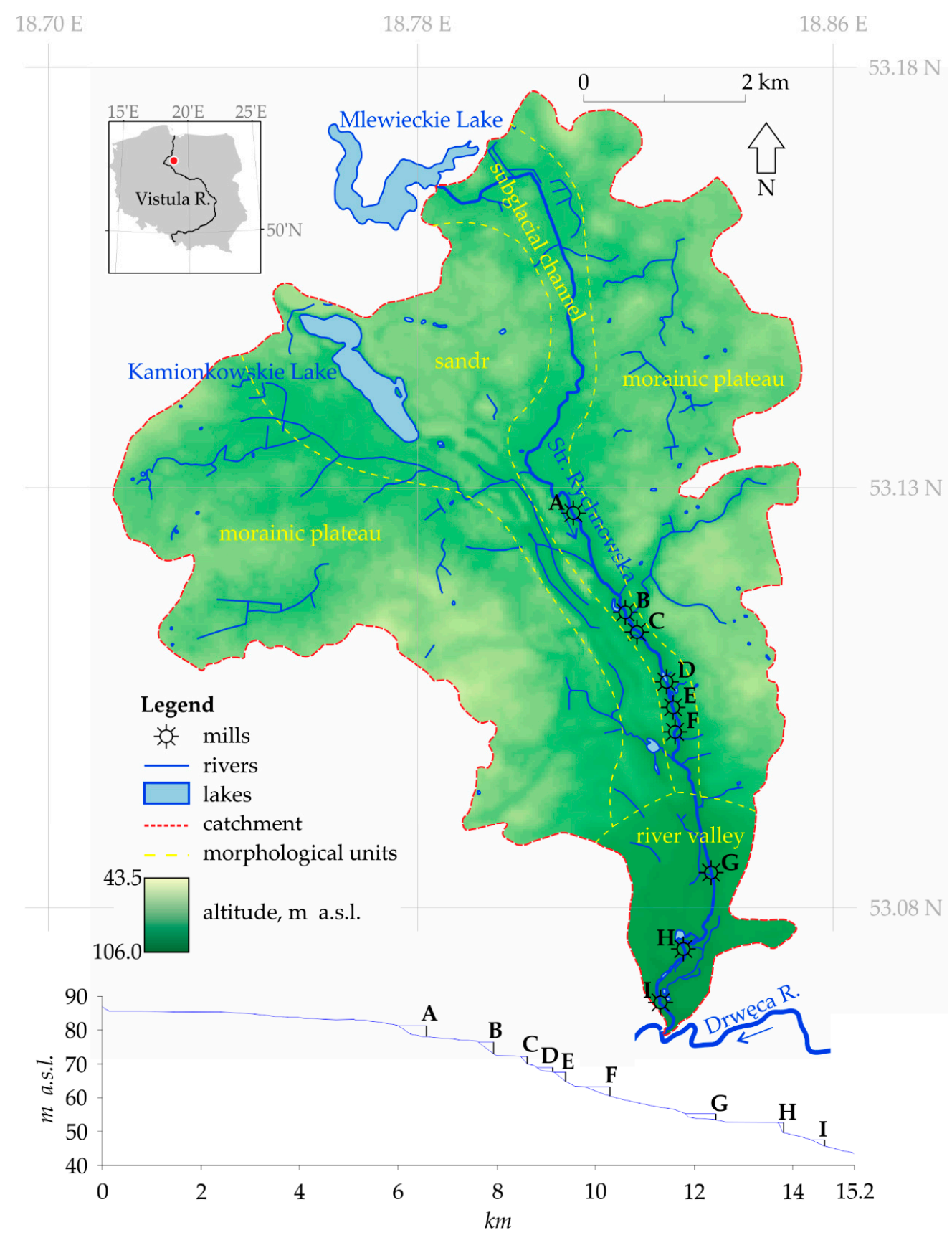

Figure 1. The Struga Rychnowska catchment with longitudinal profile of Struga Rychnowska [37-41]. Notation: Ponds: A-Oleszek, B-Juda, C-Krupka, D-Struś, E-Skrobacz, F-Papiernia, G-Szerokostaw, H-Bierzgieł, I-Pachura.

The Struga Rychnowska catchment is located in early post-glacial landscape area; it was formed during the kujawska and krajeńsko-wabrzeska subphase of the Vistulian glaciation (ca. 18-17 thousand years ago) (Figure 1). The original terrain was modified in the late Pleistocene and Holocene as a result of natural morphological processes and human activity, which began there in the early Neolithic area $[13,27]$.

The research area consists of the Neogene sediments, with base made of Pliocene clays. Quaternary deposits are 30-50 m thick. Usually, these are boulder clay layers (up to 3 levels) of different thickness, 
separated by glacilacustrine or fluvioglacial deposits. The basic morphological units in catchment area include: a fragment of morainic plateau, part of Chełmża sandr/outwash, and a subglacial channel, which is oriented NNW-SSE and is running along eastern edge of the sandr, extended by the Drwęca Valley. The origin of Struga Rychnowska channel is connected with subglacial activity of continental glacier waters in the kujawska subphase, and its further filled by winter ice. Ice melting proceeded approximately 13,000-11,000 years BP [13]. Many flow-through ponds appeared in the newly-formed melt pits in the late glacial period and in early phases of the Holocene. The ponds/lakes were separated by thresholds located in channel narrows. These ponds were slowly overgrowing, and sometimes also temporarily disappearing due to climate changes. The ponds finally declined as a result of gradual splitting of thresholds by Struga Rychnowska.

For morphological conditions, the most important for water mill locations were: the deep cutting and variable width of the channel, its local curves, the occurrence of secondary branches, and a rough bottom with many pits and thresholds. Equally important was the potential abundance of water resulting directly from the volume of waterflow, water stage fluctuations, and its decrease in longitudinal profile. Specified predispositions of the area are mostly illustrated by Figure 1 and morphometric data contained in Table 1.

Table 1. Set of morphometric parameters of selected mill ponds with an average ponding level in the years 1872-1874 [38,39,42-46].

\begin{tabular}{|c|c|c|c|c|c|c|c|c|}
\hline \multirow{2}{*}{$\begin{array}{c}\text { Name of } \\
\text { Watermill }\end{array}$} & \multirow{2}{*}{$\begin{array}{c}\text { Surface } \\
\text { Area [in ha] }\end{array}$} & \multirow{2}{*}{$\begin{array}{l}\text { Length }(\mathrm{L}) \\
\text { [in } \mathrm{m}]\end{array}$} & \multicolumn{2}{|c|}{ Width (W) } & \multirow{2}{*}{$\begin{array}{l}\text { Depth } \\
\text { [m] }\end{array}$} & \multirow{2}{*}{$\begin{array}{l}\text { Capacity } \\
\text { [thous. } \mathrm{m}^{3} \text { ] }\end{array}$} & \multirow{2}{*}{$\begin{array}{c}\text { Coefficient of Pond } \\
\text { Extension }\left(\lambda=L / W_{a v}\right)\end{array}$} & \multirow{2}{*}{$\begin{array}{r}\text { Development of } \\
\text { Shoreline }\left(\mathrm{K}^{*}\right)\end{array}$} \\
\hline & & & Max [in m] & Av. [in m] & & & & \\
\hline Krupka & 0.18 & 46 & 49 & 40.2 & 1.5 & 14.7 & 1.1 & 1.07 \\
\hline Struś & 0.30 & 101 & 43 & 29.9 & $1.0-1.4$ & 5.1 & 3.4 & 1.20 \\
\hline Papiernia & 0.52 & 224 & 35 & 23.2 & $0.8-1.3$ & 4.3 & 9.6 & 1.81 \\
\hline Bierzgieł & 0.65 & 186 & 45 & 34.9 & 1.3 & 46.2 & 5.3 & 1.36 \\
\hline Pachura & 0.67 & 215 & 49 & 31.4 & 1.4 & 12.6 & 6.8 & 1.68 \\
\hline Skrobacz & 1.20 & 221 & 87 & 54.1 & $1.3-1.5$ & 10.0 & 4.1 & 1.34 \\
\hline Juda & 1.30 & 349 & 41 & 37.1 & 1.4 & 7.6 & 9.4 & 1.75 \\
\hline Oleszek & 2.37 & 458 & 86 & 51.7 & 1.4 & 22.4 & 8.9 & 1.71 \\
\hline
\end{tabular}

${ }^{*} \mathrm{~K}$ is the relation between the length of the shoreline $(\mathrm{L})$ and the circumference of the circle whose surface area equals the surface area of the pond.

\subsection{Struga Rychnowska}

In the medieval age, Struga Rychnowska was flowing out of a vast depression south of Kamionkowskie Lake [13]. Before 1798 [45] the course of the river was extended in order to increase water flow for the purposes of water mills [2] (Figure 1, Table 2). As a result of those projects, Struga Rychnowska flows out from bifurcating Mlewieckie Lake (at altitude $86.5 \mathrm{~m}$ above sea level) and has its river mouth into the Drwęca River (altitude $43.5 \mathrm{~m}$ above sea level). The watercourse is characterized by diverse river bed, with lower levels for sections in depressions (ca. $0.5 \mathrm{~m}$ ) and higher (up to $3 \mathrm{~m}$ ) in plateau sections. As a result of introduced changes, watercourse reached $15.2 \mathrm{~km}$ in length, and the catchment area increased to $49.27 \mathrm{~km}^{2}$ [47,48]. 
Table 2. The Struga Rychnowska catchment increases according to measurements of a topographic $\operatorname{map}(1: 10,000)$ [39].

\begin{tabular}{|c|c|c|c|c|c|c|c|c|c|}
\hline \multirow[t]{2}{*}{ Profile Name } & \multirow{2}{*}{$\begin{array}{c}\text { Watercourse } \\
\text { Length (in m) } \\
\text { between } \\
\text { Profiles }\end{array}$} & \multicolumn{2}{|c|}{$\begin{array}{l}\text { Catchment Surface Area } \\
\left.\text { (in } \mathrm{km}^{2}\right)\end{array}$} & \multicolumn{2}{|c|}{$\begin{array}{c}\text { Altitude (m above Sea } \\
\text { Level) }\end{array}$} & \multicolumn{4}{|c|}{$\begin{array}{c}\text { Watercourse Valley Bottom Fall } \\
\text { (in \%o) }\end{array}$} \\
\hline & & Increment & Sum & above mill & below mill & $\begin{array}{l}\text { between } \\
\text { Profiles }\end{array}$ & Av. & $\begin{array}{l}\text { between } \\
\text { Profiles }\end{array}$ & Av. \\
\hline Mlewieckie L. & 0 & 0 & 0 & \multicolumn{2}{|c|}{86.5} & 0 & 0 & 0 & 0 \\
\hline Oleszek & 6580 & 15.06 & 15.06 & 79.5 & 77.6 & 1.06 & 1.06 & 1.35 & 1.35 \\
\hline Juda & 1355 & 19.80 & 34.86 & 76.2 & 72.5 & 2.44 & 1.30 & 3.76 & 1.76 \\
\hline Krupka & 695 & 3.06 & 37.92 & 71.8 & 69.8 & 6.33 & 1.71 & 3.88 & 1.94 \\
\hline Skrobacz & 765 & 0.67 & 38.59 & 67.3 & 64.5 & 5.88 & 2.05 & 6.93 & 2.34 \\
\hline Struś & 230 & 0.32 & 38.91 & 64.6 & 63.0 & 11.74 & 2.28 & 2.52 & 2.44 \\
\hline Papiernia & 670 & 0.43 & 39.34 & 62.5 & 60.4 & 3.13 & 2.33 & 3.88 & 2.54 \\
\hline Bierzgieł & 3525 & 7.81 & 47.15 & 52.5 & 49.6 & 2.84 & 2.46 & 3.06 & 2.67 \\
\hline Pachura & 835 & 1.44 & 48.59 & 47.0 & 45.5 & 6.59 & 2.70 & 4.91 & 2.80 \\
\hline Drwęca R. & 675 & 0.68 & 49.27 & \multicolumn{2}{|c|}{43.5} & 5.26 & 2.83 & 3.03 & 2.83 \\
\hline
\end{tabular}

\subsection{Runoff Conditions}

Among all climate elements, total precipitation is most important for water mill functioning. In multiannual cycles, the analyzed area is characterized by low average annual precipitation, which affects the volume of renewable resources in the catchment. For the nearby Chełmża Station (around $8 \mathrm{~km}$ in the north-west direction from Kamionkowskie Lake), the value determined for the average annual precipitation across the years 1960-1980 is $586 \mathrm{~mm}$ [2]. In an annual cycle, precipitation between May and October prevails-ca. $65 \%$ of average annual precipitation. On the average, there are 159 days per year with precipitation.

A distinct lead of the underground water supply (ca. $70 \%-75 \%$ ) is observed in the Struga Rychnowska system, continuously all over the year [49]. Intense water supply occurs in two periods during a year. The first one is from February until April, when intense snowmelt is followed by inhibited water penetration into frozen ground. The second phase of increased water supply is observed in July, due to heavy rainfall. Currently, the majority of occurrences of the highest water level in a hydrological year are in the winter half-year (95\%). The lowest water levels occur primarily in July (35\%).

In the analysed area, runoff $(\mathrm{q})$ is smaller than average for Poland (this affects the rate of bottom sediments accumulation in the ponds in the specified sub-catchments) ranging from 3.94 to $4.14 \mathrm{dm}^{3} \mathrm{~s}^{-1} \mathrm{~km}^{-2}$. It is also smaller than the average runoff for selected rivers of Eastern Europe $\left(4.6 \mathrm{dm}^{3} \mathrm{~s}^{-1} \mathrm{~km}^{-2}\right)$ or Central and Western Europe $\left(10.0 \mathrm{dm}^{3} \mathrm{~s}^{-1} \mathrm{~km}^{-2}\right)$ [50]. Flow levels calculated for the Skrobacz-Struś section are: mean low water- $0.054 \mathrm{~m}^{3} \mathrm{~s}^{-1}$; summer high water-4.896 $\mathrm{m}^{3} \mathrm{~s}^{-1}$; winter high water-7.061 $\mathrm{m}^{3} \mathrm{~s}^{-1}[51]$.

\subsection{Methods}

The data from historical sources and archive cartographic materials allowed determining the construction and operation dates for water mills and neighboring ponds [42-46,52-59]. Surface areas of mill ponds located in the bottom of the Struga Rychnowska channel were calculated on the basis of enlarged aerial photos and topographic maps [39,41-46,53-56].

Two ponds were chosen for a detailed analysis: Bierzgieł and Oleszek (Tables 1 and 2). The results of both geomorphological mapping $[37,38]$ and analyses of bottom sediments were used to reconstruct the genesis and history of mill ponds [13,42-46,52-59]. Field works carried out in Bierzgieł and Oleszek mill ponds in the years 1999-2001, 2013, and 2019 allowed specifying bottom sediment layer thickness, identifying their basic physical features, determining accumulation rate, and sediment sampling.

Laboratory analyses were performed to determine grain composition and content of organic matter and carbonates for 37 sediment samples from the reservoir in Oleszek (from all sedimentary layers with 6 trenches-cross sections: A-90 cm, B-100 cm, C-60 cm, D-100 cm, E-60 cm, and 
$\mathrm{F}-125 \mathrm{~m}$ ) and for 17 sediment samples taken from the Bierzgiel pond basin (from all sedimentary layers with 3 trenches-cross sections: G-120 cm, H-50 cm, and I-130 cm).

Grain composition was examined using the following methods: sieve [60]—sand and gravel sediments, laser with LPS "analysette 22" [61]—silt and clay sediments, and combined—diamicton type sediments (multi-fraction). The results were processed using distinctions and nomenclature according to the standard by Polish Geological Institute in Warszawa [62].

Organic matter and carbonate contents were determined using the gravimetric method-the samples were burned in muffle furnace at the temperatures $550{ }^{\circ} \mathrm{C}$ and $925^{\circ} \mathrm{C}$, respectively. Mass decrement after roasting was identified with organic matter content in the first case, and with carbonate content in the second case $[63,64]$. Organic matter and carbonate content analyzed using this method were compared to the classification of lake deposits from Rzepecki [65].

A few statistical indicators of graining were used to determine sediment origin and to interpret the dynamics of depositional environments. It was decided that average grain diameter $(\mathrm{Mz})$, sorting $\left(\sigma_{1}\right)$, skewness $\left(\mathrm{Sk}_{1}\right)$, and flatness $\left(\mathrm{K}_{\mathrm{G}}\right)$ would be good indicators of depositional environment, taking into account diversity of transport energy and transport duration [66]. Additionally, first percentile (C) and median $(M)$ were used to evaluate transportation methods of fluvial sediments $[67,68]$.

Moreover, palynological analyses for 11 samples of biogenic sediments [29], and 2 peat samples' [2] age determination by ${ }^{14} \mathrm{C}$ dating method done at the Laboratory of the Institute of Physics of the Silesian University of Technology-were performed for sediments deposited in Oleszek pond (Gd-12365; Gd-12363). We calibrated radiocarbon dates with "IntCal 13" software [69]. Palynological expertise was carried out at the Palynological Laboratory of the Nicolaus Copernicus University in Torun. The samples were prepared according to the methodology recommended by Berglund and Ralska-Jasiewiczowa [70]. From the sediment ( $40 \mathrm{~cm}$ of monolith), the top sample did not have sporomorphs (i.e., spores and pollen grains). However, three bottom samples, due to the poor condition of the materials, were not included in the diagram. Because all the sedimentary materials contained small mineral parts, they were macerated for 4 days with hydrofluoric acid (HF), and only then the acetolysis method by Erdtman [71] was done. The results are presented in the form of a percentage diagram. The sum of trees (AP) and herbaceous plants (NAP) was used as the basis for percentage calculations. Pollen material from shrubs was included in the sum of trees, and prostrate shrubs in herbaceous plants. Spores and pollen of local plants were excluded from the total, but their contribution was also calculated in relation to AP $+\mathrm{NAP}=100 \%$. The diagram first includes the curves of Pinus sylvestris and Betula against the background of the ratio of trees to herbaceous plants; then, the curves of other trees, herbaceous plants, and local plants excluded from the sum of local plants.

Waterflow analysis was carried out in order to determine sedimentation conditions in mill ponds. The analyses were based on an indicator-water retention time, calculated as the ratio of average annual water runoff from catchment (in a given profile) to pond capacity [72]. Capacities of mill ponds were compared to the volumes of average annual runoff from sub-catchments. Calculations were performed for maximum pond capacities (highest known water level).

\section{Results}

\subsection{Construction and Operation of Water Mills in the Struga Rychnowska Catchment}

The oldest transformations of landscape features and surface water due to the construction of water mills were documented in the area in the first half of the 14th century. Individual locations of water mills were chosen while the area belonged to the Order of Brothers of the German House of Saint Mary in Jerusalem and the Culmer Handfeste law was in force. Regal privileges defined the locations of watermills, the damming, and the changing of the courses of rivers. The mills in the lower watercourse section were built during the first stage of water mill location, before the turn of 14th and 15th centuries. When the analyzed area was incorporated into Poland in 1466, six of the nine water 
mills described were in operation (Figure 2). In 1772, the mill in Oleszek was built as the last one, and provided with a retention pond of the largest capacity (Figure 2).

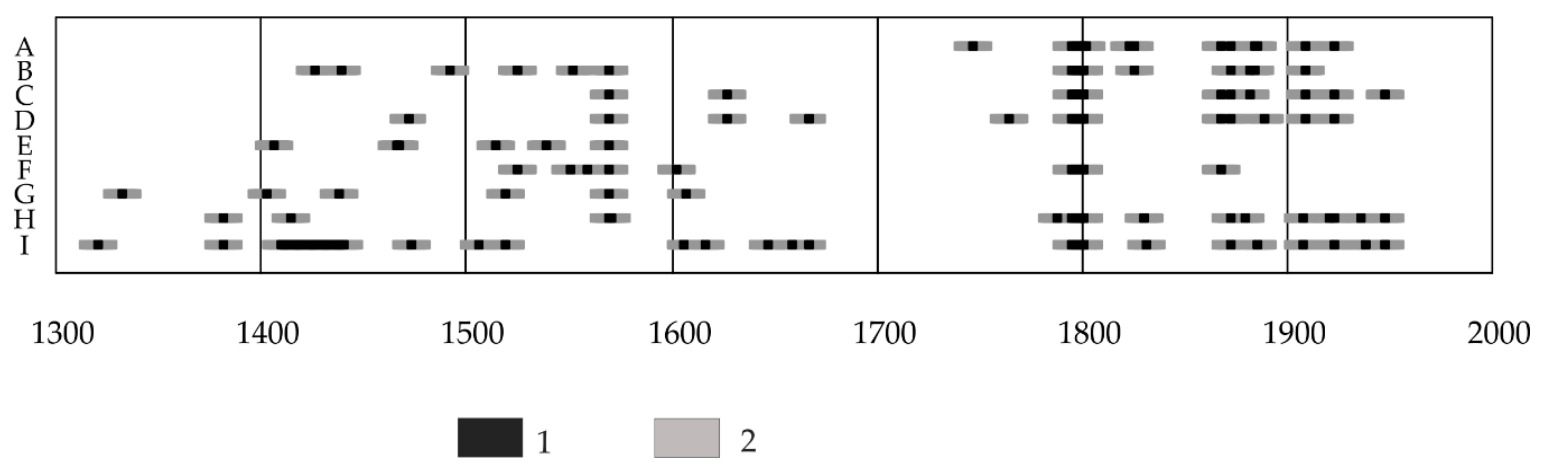

Figure 2. Operation of water mills in the Struga Rychnowska catchment. Notation: periods of watermill operation: 1—confirmed, 2-conjectured; ponds A-I: as in Figure 1.

The locations of water mills were analyzed in detail due to separate physiographic features. Their systems of water supply to the mill, the water retention method, and the discharge after use were different. Detailed studies show that at the Bierzgieł mill water retention took place in a pond built on a mill channel, by way of separating bottom section with a dyke (Figure 3). Water supply for this pond was controlled with a weir located below mill stream outflow. Water, after use, was discharged via mill stream into the river. On the other hand, retention water for the Oleszek mill was kept in a flow pond built at the back of a dyke built across the valley's axis. After use, water was discharged straight into the river, whereas surplus retention water was sent to the bypass channel flowing into the river (Figure 4). 


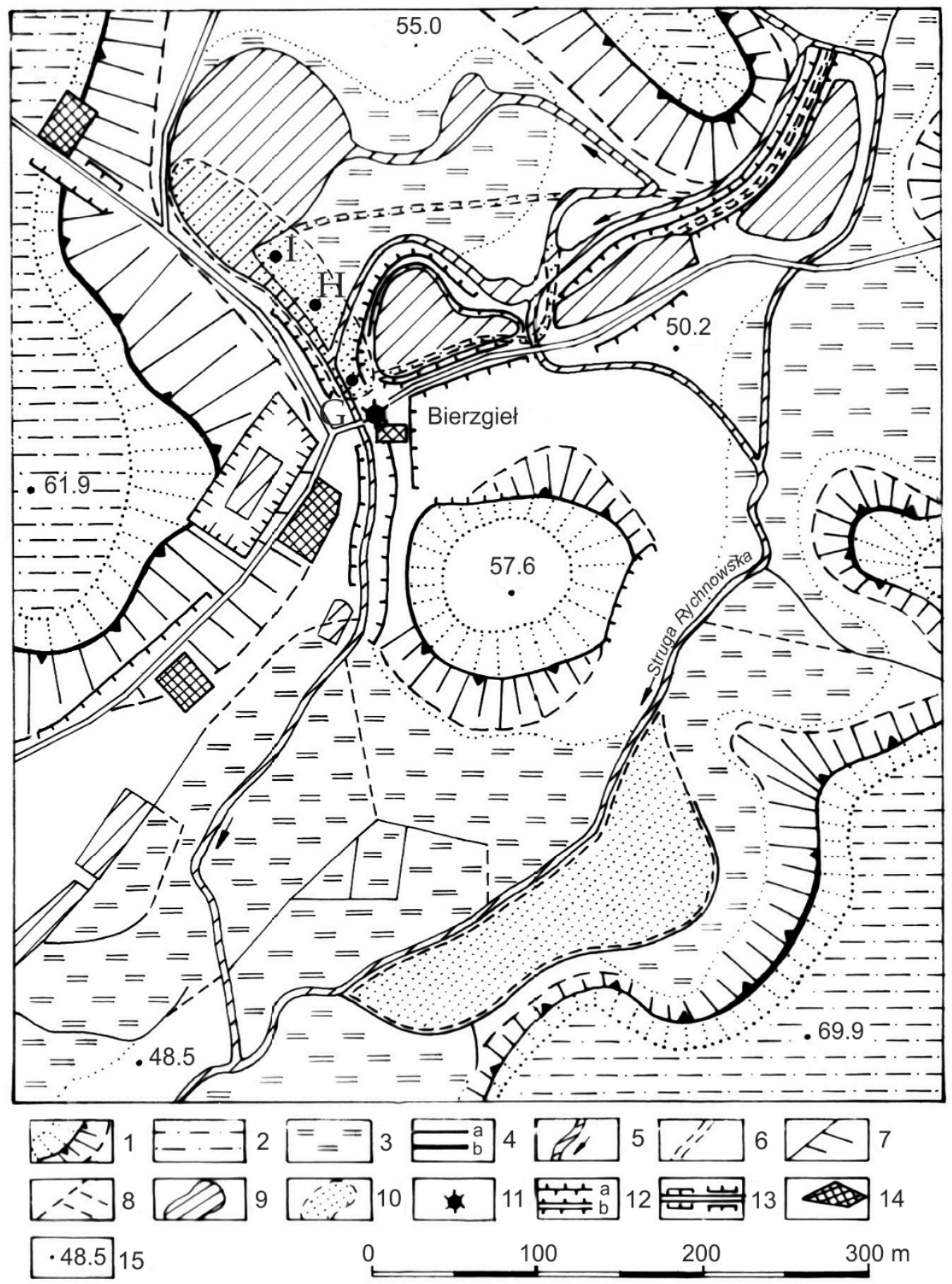

Figure 3. The Bierzgieł site on Struga Rychnowska. Notation: 1—subglacial channel: escarpments with degradation and aggradation zones, 2-ice marginal streamway erosional terrace, 3-biogenic plain, mainly peat, 4-upper slope escarpments with relative heights of (a) up to $10 \mathrm{~m}$ and (b) 10-20 m, 5-existing watercourses, 6-artificially deepened or widened watercourse channels, 7-existing melioration ditches, 8-non-extant melioration ditches, 9-water reservoirs, 10-outline of the mill pond basin in 1873, 11—watermill location, 12-dykes and (a) and dams (b), 13-road incisions and embankments, 14-levelled surfaces, 15-absolute heights. 


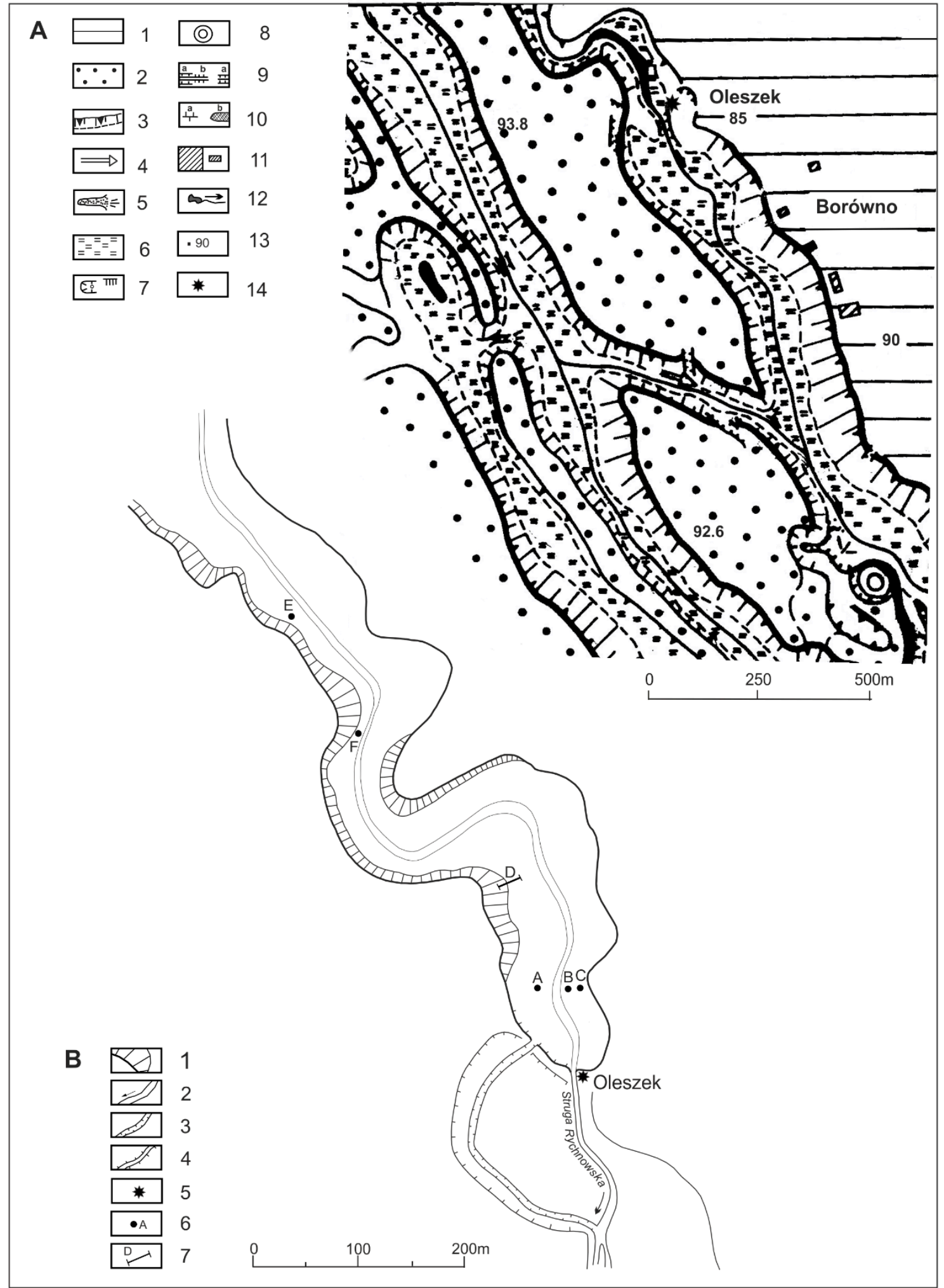

Figure 4. The Oleszek site on Struga Rychnowska. Notation: (A) The geomorphological map: 1-flat moraine plateau, 2-outwash, 3-subglacial channels, 4-melt water valleys, 5-Holocene V-shaped valleys of the gully type, 6-biogenic plains, mainly peat, 8-mediaeval stronghold, 9-road incisions (a) and embankments (b), 10—dykes (a) and dams (b), 11—farmsteads, 12-water reservoirs and watercourses, 13-absolute heights, 13-watermill location; (B) 1-break and gentle slope of mill pond basin, 2-watercourse, 3-bypass channel, 4-dyke, 5-watermill locations, 6-investigated profiles, 7-profile line. 
The dates of Bierzgieł and Oleszek mill pond construction are not precisely known. The oldest historic note concerning Bierzgieł mill dated 1382 contains no information on the mill pond. However, interpretation of other historic notes indicates that Bierzgiel pond was in use at the beginning of the 15th century, whereas, Oleszek pond (as indicated by age of peat sediments and settlement development in the nearby Borówno) was formed at the beginning of the 18th century, or at the latest before 1747 . The oldest outline of Oleszek pond is shown in the Zimmerman plan of 1798. In order to lift Struga Rychnowska waters, a flow-through mill pond with surface area of ca. 2.5 ha was set in the basin of the disappearing lake.

The areas of the ponds changed many times. The Bierzgieł pond was at its largest at 1910-3.56 ha, and at its smallest at 1873-0.65 ha. On the other hand, the pond in Oleszek had the highest water level at the beginning of the 19th century, and the lowest $(3.5-3.7 \mathrm{~m})$ at around 1873. As a result of this, the pond backwater reach dropped from ca. $820 \mathrm{~m}$ to ca. $460 \mathrm{~m}$. Their detailed morphometric characteristics are contained in Table 3.

Table 3. Changes in selected morphometric features of mill ponds at the turn of the 19th and 20th centuries.

\begin{tabular}{|c|c|c|c|c|c|c|c|}
\hline \multirow{2}{*}{$\begin{array}{l}\text { Name of } \\
\text { Watermill }\end{array}$} & \multirow{2}{*}{ Year } & \multirow{2}{*}{$\begin{array}{l}\text { Surface Area } \\
\quad \text { (in ha) }\end{array}$} & \multirow{2}{*}{$\begin{array}{l}\text { Length (L) } \\
\quad \text { (in } \mathrm{m} \text { ) }\end{array}$} & \multicolumn{2}{|c|}{ Width (W) } & \multirow{2}{*}{$\begin{array}{l}\text { Coefficient of Pond } \\
\text { Extension }(\lambda)\end{array}$} & \multirow{2}{*}{$\begin{array}{c}\text { Development } \\
\text { of Shoreline (K) }\end{array}$} \\
\hline & & & & Max (in m) & Av. (in m) & & \\
\hline \multirow{3}{*}{ Bierzgieł } & 1873 & 0.65 & 186 & 45 & 34.9 & 5.3 & 1.36 \\
\hline & 1910 & 3.56 & 369 & 223 & 96.4 & 3.8 & 1.28 \\
\hline & 1992 & 1.03 & 107 & 103 & 96.0 & 1.1 & 1.04 \\
\hline \multirow{4}{*}{ Oleszek } & 1798 & 4.29 & 819 & 101 & 52.3 & 15.6 & 1.97 \\
\hline & 1802 & 4.38 & 809 & 109 & 54.2 & 14.9 & 1.85 \\
\hline & 1873 & 2.37 & 458 & 86 & 51.7 & 8.9 & 1.71 \\
\hline & 1924 & 2.60 & 615 & 74 & 42.2 & 14.6 & 2.28 \\
\hline
\end{tabular}

\subsection{Characteristics of Sediments in Oleszek and Bierzgiet Ponds}

The oldest sediments found in Oleszek document final phases of functioning of these ponds (Figure 5, profile F: 85-125 cm). These are: silts (clayey or clay-sandy), gyttjas (silty or silty-limestone), and peats. Therefore, the lower peat layer (Figure 5, profile F: 100-103 cm; preserved in form of decay) was formed at the beginning of 13th century. On the other hand, the upper peat layer (Figure 5 , profile F: $85-95 \mathrm{~cm}$ ), contained $5.4 \%$ carbonates and $60.1 \%$ mineral parts. The initial period of the pond functioning is documented by silt-limestone gyttja lying on peat (Figure 5, profile F: $80-85 \mathrm{~cm}$ ), containing $23.1 \%$ organic matter and a high content of carbonates (reaching $48.1 \%$ ). The process of peat formation in Oleszek pond was interrupted. The upper layer is silt-limestone gyttja (Figure 5, profile F: $75-78 \mathrm{~cm}$ ), containing $23.8 \%$ organic matter and $22.2 \%$ carbonates. The layer from this period consists of clayey silt with high carbonate content- $15.1 \%$ (Figure 5, profile F: $72-75 \mathrm{~cm}$ ). The overlying layer (Figure 5, profile F: $60-70 \mathrm{~cm}$ ) contains very low contribution of organic matter $(1.1 \%)$ and carbonates (2.1\%). The layer 65-68 cm (Figure 5, profile F) consists of clayey-sandy silt with minor contents of organic matter $(2.2 \%)$ and carbonates $(6.2 \%)$. The diversity of graining in sandy-clayey silts which defines layers in Figure 5, profile F $(62-65 \mathrm{~cm})$ and Figure 5, profile $\mathrm{F}(60-62 \mathrm{~cm})$, is relatively small. The results of different contents of organic matter $(1.1 \%$ and $5.1 \%$, respectively) and carbonates $(2.8 \%$ and $12.6 \%$ ) are significant. 
Organic Matter
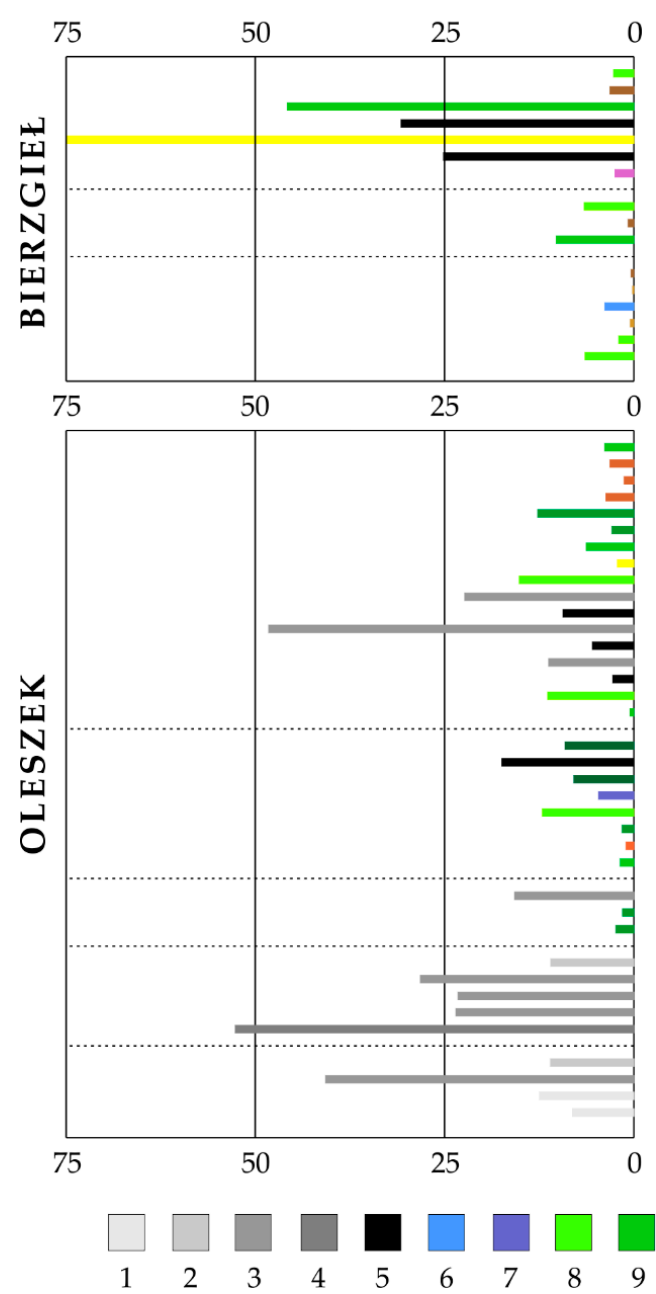

$0 \quad[\%]$
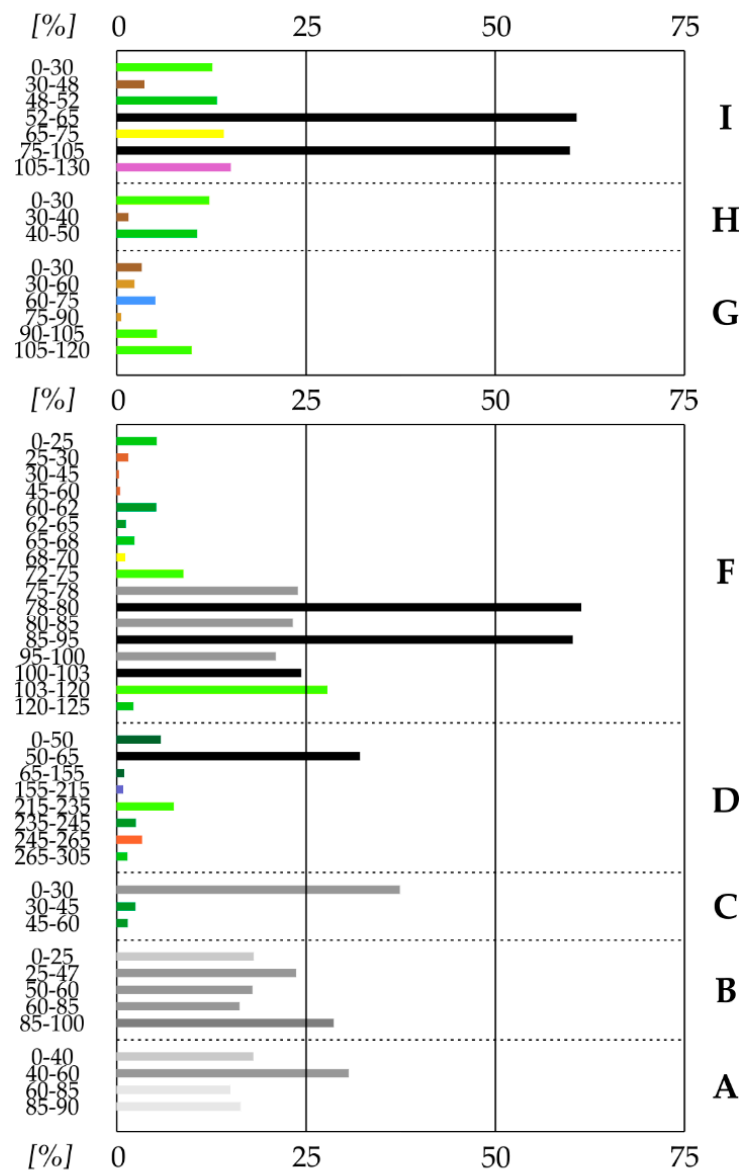

Figure 5. Concentration (\%) of organic matter and carbonates in selected depths of sediments of Bierzgieł and Oleszek mill ponds. Notation: A-I-investigated profiles like those on Figures 3 and 4; sediment classifications: 1 - silty-clay gyttja, 2-silty gyttja, 3-silty-limestone gyttja, 4-limestone gyttja, 5-peat, 6-silty-sand clay, 7—sandy clay, 8-clayey silt, 9-clayey-sandy silt, 10—sandy-clay silt, 11—sandy silt, 12—silty-clay sand, 13 - clayey fine sand, 14-fine sand, 15-fine sand with gravel, 16-medium sand, 17—sandy gravel.

Sediments in Oleszek pond are lake type biogenic sediments (gyttjas and peats prevail), and poorly and very poorly sorted $\left(\sigma_{1}=1.23-3.09\right)$ silts and organic clays $(\mathrm{Mz}-3.98 \varphi-6.88 \varphi)$ dominate among mineral sediments. The average $\mathrm{Mz}$ value is $4.73 \varphi(0.037 \mathrm{~mm})$ with extreme values from $1.59 \varphi$ $(0.33 \mathrm{~mm})$ to $6.88 \varphi(0.009 \mathrm{~mm})$, and a definite majority of samples have Mz values in the range of $4.0-5.0 \varphi$. These deposits are, therefore, very fine-grained, and their degree of sorting weak or very poor. The average sort value is 1.91 (at extreme values: $0.92-3.09$ ). Skewness values vary. In a similar proportion they are both negative and positive-skewed, as well as symmetrical.

Two sediment groups with different volumes can be distinguished in Bierzgieł pond: (A) sandy-silty sediments, and (B) silty-clayey sediments. Graining parameters of the distinguished sediment groups are as follows: (A) moderately, poorly, and very poorly sorted $\left(\sigma_{1}=0.6-2.44\right)$ sands and silty sands with gravel $(\mathrm{Mz}--1.85 \varphi-3.97 \varphi)$; and $(\mathrm{B})$ poorly and very poorly sorted $\left(\sigma_{1}=1.41-2.44\right)$ silts and organic clays $(\mathrm{Mz}-4.52 \varphi-7.36 \varphi)$.

Palynological analyses confirmed radiocarbon dates from bottom (710 $\pm 40 \mathrm{cal} \mathrm{BP}-1240$ AD) and top (530 $\pm 45 \mathrm{cal}$ BP-1420 AD) layers of the analysed sediments. The result of palynological studies is a pollen diagram (Figure 6). Grains of Pinus sylvestris (average 52.9\%) dominate in all spectra of 
the measured sediments; Almus (11.4\% average) has a lower occurrence. Betula, Carpinus betulus, Quercus, and Salix are represented by continuous curves but with values not exceeding 10.0\%. Fagus, Tilia, Populus, and Ulmus pollen grains occur sporadically. Of the shrubs, Corylus avellana is the most abundant; the Juniperus communis pollen, and single grains of Rhamnus carhartica and Sambucus were also found. Among the herbaceous plants (NAP) presented in the diagram, next to Gramineae undiff. and Cyperaceae, there is a contribution of taxa considered as anthropopressure indexes: including cultivated plants_rye (Secale cereale), other cereals (Ceralia undiff.), millet (Fagopyrum), weeds cereals such as Centaurea cyanus; animal grazing indicator-Plantago lanceolate, P. maior/media, Melampyrum, Calluna vulgaris, and Rumex; ruderal species-Artemisia, Urtica, Chenopodiaceae and Asterioodeae undiff., Cichorioideae undiff. Local vegetation is represented by Equisetum and cenobia of Pediastrum. The [ollen of such reed plants also appeared in smaller amounts: Sparganium, Typha latifolia, Myriophyllum spicatum, Nyphaea, Potamogeton, and Lemna. One pollen grain of the Stratiotes aloides plant, which is rare today, was found.

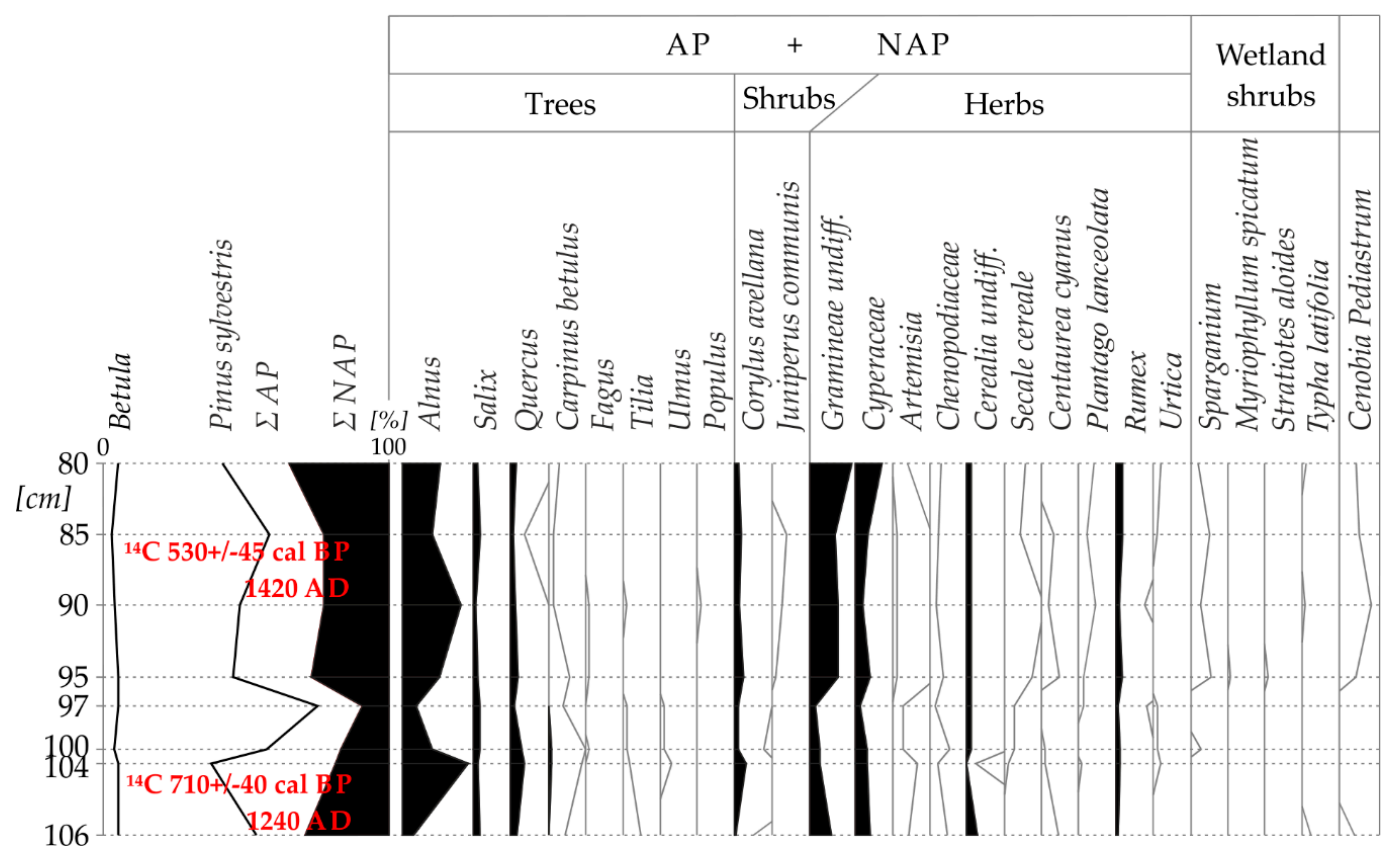

Figure 6. The Oleszek pollen diagram (selected plants).

\section{Discussion}

\subsection{Construction and Operation of Water Mills in the Struga Rychnowska Catchment}

Over the last 200 years, the changes in landscape features and surface water resulted from the development and modernization of water mills [1,2]. An analysis of historical cartographic materials shows that the water supply and drainage systems have been adapted to their new purposes. In the case of the Bierzgieł mill (Figure 3) mill pond and mill ditches were modified [43,44]. In the case of the Oleszek pond (Figure 4), to increase retention capacity, a drainage channel from arable areas was provided $[45,46]$. Also, new surfaces for mill buildings and storehouses levelled and access roads widened $[2,43,44]$. The discussed trend was imposed by changes in runoff conditions, and very rapid technological progress, including the introduction of water turbines since 1849. The fact that side milling production (e.g., papermaking and fulling) started to become independent in the 19th century [73] was relevant in many cases of water mill decommissioning; e.g., the Papiernia mill [2,57]. Also, mill decommissioning was the effect of replacing water drop energy by steam machines, and from the end of the 19th century-of steam engines and electric motors [74] and transformations of the socioeconomic system in Poland after World War II [1]. 
Due to the fact that both Oleszek and Bierzgieł water mills were decommissioned in 1950s, it is hard to determine the processes and the rate of bottom sediments' accumulation in the ponds prevailing more than seven decades ago. Therefore, to evaluate the changes in the sediments of the mill ponds, it is crucial not only to determine the date of their last clearing (dredging or emptying in order to erode bottom sediments), but also to divide them into layers connected to the deposition in conditions of normal water mill functioning and in the period of using it for retention purposes only. Therefore, approximate size and progress of this process can be concluded only on the basis of completed field studies and selected results $[2,29,31]$.

\subsection{Sedimentation in Bierzgiet and Oleszek Ponds}

The basins of Oleszek and Bierzgieł mill ponds were formed in much the same way-both were developed in the bottom of subglacial channel cut by snowmelt water during the Vistulian glaciation [13]. Later, during continental glacier stagnation, the channel was secured by glacier ice blocks or winter ice. In the Alleröd (approximately 11,800-10,700 years BP), the eastern branch of the channel-the Oleszek reservoir basin-was exhumed, whereas ice melting in lower section of the channel (Bierzgiet reservoir basin) could have occurred even earlier, under the impact of waters flowing towards the Drwęca Valley [13]. The second stage of basin formation started when thresholds emerged and water filled pits appeared in channel bottom. Thus, it initiated the phase of the natural flow-through water reservoirs. The nature and structure of the oldest sediments (Figure 5, profile F:85-125 cm) indicates that they were deposited by slowly flowing waters, and pond depth was changing a lot. These changes resulted from either annual rhythm of its supply with water and climate fluctuations, changes in catchment surface development, or slow threshold cutting by Struga Rychnowska. The upper peat layer (Figure 5, profile F: $85-95 \mathrm{~cm}$ ) was formed as a consequence of evident pond shallowing. It was particularly visible in upper part of the pond and in its shore areas. Therefore, peat layer occurrence was not observed in other pond sections, where different environmental conditions prevailed. The cyclic appearance of hygrophilous plants is another proof of water table fluctuations in already shallow Oleszek pond. Then, Bierzgieł pond probably declined as a result of threshold cutting and water runoff, whereas, Oleszek pond existed in its residual form in the 16th century, meaning that most probably lake decay process was not complete before construction of water mill. The sediment (Figure 5, profile F: 80-85 cm) was formed in the shore zone. Also, there were a lot of the remains of mollusk shells. In its central section (Figure 4-profiles A and B), the pond was slightly more fertile than in its upper part, and evidently more stable. Undoubtedly, the flow characteristics of the pond supported good oxygenation of water, and bottom direction of water mass movement was different than the course of Struga Rychnowska riverbed today. The sediment layer 75-78 cm (Figure 5, profile F) was developing in conditions typical for a deep reservoir. The high carbonate content in sediment layer (Figure 5-site F: $72-75 \mathrm{~cm}$ ) was due to the presence of numerous concentrations of small shells, and probably also precipitation of carbonates, which were occasionally washed out from exposed (emerged from water) fractions of older bottom sediments and re-accumulated in water [31]. Periodic water level fluctuations in the reservoir directly related to the operation of the water mill were adopted as the main reason for this process. Identified among others, were shells of Anodonta cygnea and Unio tumidus. These species reach the highest abundance in reservoirs with high trophy. They are sensitive to water pollution and oxygen deficits [75]. The increased carbonate content was probably also due to the biogenic precipitation, but sediments have not been studied in this aspect. The upper layers are a material embedded in flowing water; e.g., mud loam sand (Figure 5-site F: 60-70 cm).

As a result of Oleszek mill decommissioning at the beginning of World War II, water was discharged from the pond. This is proven by deep cut of layers (Figure 5-site F: 60-75 cm). However, later water level was lifted again, and the restored water reservoir was used for retention purposes even in the 1950s. The nature of sediments from this period proves that water level was considerably lower, and sandy series formations were settling in short time and at variable flow rate. In some sections of the pond directly next to channel slopes, river sediments are covered by deluvia. Mass movements 
were fostered by water escapes and seepages occurring in this level. Whereas, as regards Bierzgieł mill, it is known that it was still working in 1948.

Two ponds were formed in the basin after Bierzgieł mill decommissioning in the 1950s, whereas water flow-off from Oleszek reservoir was abrupt in nature. This conclusion can be drawn from the fact that silt-limestone gyttjas appear directly on the surface in A-C profiles (Figure 5). Pond elimination resulted in rapid deep-seated erosion process. Within ca. 50 years, some bottom sediments deposited in natural water reservoir and then covered by mill pond sediments and fractions of river sands were cut in profile $\mathrm{F}$ to the depth of ca. $1.5 \mathrm{~m}$. Meadow soil developed on sediments filling basin bottom, which were transported out of the watercourse bed. Decommissioning of the mill pond in Oleszek was the result of drastic drop in Struga Rychnowska water supply volume. The immediate reason was the construction in the late 1940s and early 1950s of a water lifting weir on the river at the mouth from Mlewieckie Lake, which limited water inflow almost only to spring flood periods [76].

The vegetation development phase, which can be traced using a pollen diagram, should be attributed to the sub-Atlantic period. Based on cereal curves, and especially Secale cereale, whose values in some spectra exceed $1.0 \%$, it can be thought that it refers to the younger part of the sub-Atlantic period. Palynological analyses were confirmed by radiocarbon dates from the bottom and top layers of the tested sediment. The poor condition of sporomorphs in the bottom part of the examined profile indicates that the sediment was deposited in unstable or low water levels in contrast to the sediment from a depth of 80-97 cm. The sediments of the ceiling section of the profile accumulated under relatively stable conditions of not very high water level. This is evidenced by the constant presence in this section of the profile of the Pediastrum cenobites, as well as pollen grains of aquatic and reed plants.

Analysis of distribution of these sediment samples in the C/M diagram of R. Passega $[67,68]$ allows concluding that these sediments were accumulated primarily from homogeneous suspension, with minor contributions from grains transported in traction-both at low flows and from a homogeneous suspension in still water. The maximum flow rate of water in the reservoir, determined on the basis of the interpretation of the distribution of the value of the first percentile $(C)$ on the diagram of A. Sundborg [77,78], was at least $0.5 \mathrm{~m} \mathrm{~min}^{-1}$. It was found in relation to a series of sediments at the river mouth to the pond in which normal fractional graining occurs in the layer of sands and silts. Their deposition occurred at an increasing speed of water flow, from about one to several meters per second. Sedimentation in the central part of the reservoir took place under slightly higher flow conditions, at a river speed of a few to about $10 \mathrm{~m} \mathrm{~min}^{-1}$. Compared to bottom sediments in other dam reservoirs at mills analyzed within Chełmińskie Lake District, sediments in Oleszek pond are the most fine-grained and the least sorted [31].

The rate of sediment accumulation in the Bierzgieł pond, located on the mill ditch, is demonstrated by the thicknesses of the bottom sediments deposited in the central part of this reservoir (Figure 3-site I). The sediments document the period from around 1910 (time from the change of the surface of this reservoir) to 1939 (until the water mill stopped working). This means that for about 29 years, slit and sand sediments were accumulated with a thickness of about $1.25 \mathrm{~m}$. In the given period, the accumulation rate remained at the level of about $4.3 \mathrm{~cm}_{\text {year }}{ }^{-1}$. However, it cannot be excluded that the pond was cleaned during this time.

In the case of the flow-through pond in Oleszek, only the rate of accumulation in the coastal part of the upper section of the reservoir could be determined (Figure 4-site F). The period of functioning of the pond covering the aforementioned site, documented in historical sources, began in 1798, which corresponds to the silt-limestone gyttja $(80-85 \mathrm{~cm})$ lying on peat. In turn, the youngest sediment deposited in this profile is clay-sandy slit with organic matter. After the liquidation of the water mill (around 1939), the water of the Struga Rychnowska was raised in a retention reservoir, the range of which no longer covered the F site. It was assumed that over a period of about 141 years, the sediment accumulation rate was only $0.6 \mathrm{~cm}_{\text {year }}{ }^{-1}$. 
The results of research obtained by other authors show that the rate of bottom sediment accumulation in mill ponds can reach very different values: $3.2 \mathrm{~cm}_{\text {year }}^{-1}$ [17]; $0.5 \mathrm{~cm}_{\text {year }}{ }^{-1}$ [24]; $5.4 \mathrm{~cm}$ year $^{-1}$; and $7-8 \mathrm{~cm}_{\text {year }}^{-1}$ [2].

The studies on the dynamics of mill pond sedimentation process make an excellent supplement to the research on denudation volume in those catchments, for which monitoring data is unavailable. Runoff denudation volume (suspended material transport) from catchments located in the area of Chełmińskie Lake District ranges from 2 to $3 \mathrm{t} \mathrm{km}^{-2}$ year $^{-1}$ [79]. According to the results of studies by Michalska and Szpikowski [17], it can be assumed that in case of the mill ponds we analyzed, deposition imposed by the conditions in these ponds could have been ca. $60 \%$ of bedload volume carried out of the catchment in the suspended form. It should be also noted that these studies allow not only determining current denudation intensity, but also estimating denudation volumes in historic times. This data can be used in modelling of rubble transport dynamics in small catchments depending on climate changes.

\subsection{Water Retention Time}

The rate of dam reservoir silting up is inversely proportional to the rate of water exchange in these reservoirs [80]. An analogical relationship applies to mill ponds as well. Water exchange of this sort, imposed by flow-through nature of the pond, should by qualified as the so-called horizontal exchange, taking into account only the volume of water flowing through the pond and contained in it. The volume of this exchange is given by water retention time, which may be considered as an indicator of pond hydraulic loading with mineral and organic matter originating from the entire catchment.

Completed analyses indicate that mill ponds were reolimnic type flow-through reservoirs. It means that water was exchanged more than 10 times per year [72]. Water retention time in millponds fluctuated from 0.35 to 11.39 days, and this value was dependent on its capacity. For example, water retention time in Oleszek pond located in upper part of the watercourse, with maximum capacity ca. $61,300 \mathrm{~m}^{3}$ and average annual flow $62 \mathrm{dm}^{3} \mathrm{~s}^{-1}$, reached over 11 days, and in Bierzgieł pond situated further down the watercourse, with capacity $46,250 \mathrm{~m}^{3}$ and average flow $186 \mathrm{dm}^{3} \mathrm{~s}^{-1}$-it was less than 3 days. Highly diverse water retention times indicate extremely different pond functioning conditions, in spite of their locations being in the same catchment. This is a result of the impact of the above-mentioned natural and anthropogenic determinants. The most important of them were: pond location with reference to the main river, and morphometric parameters. Considering this, water retention time in mill ponds depended most on the intensity of anthropogenic impact on the environment. Very short water retention time in flow-through mill ponds was also pointed out by Jespersen [81], who observed that most of multiple wheel mills operated in Denmark used water accumulated overnight during the next working day. This regularity was also confirmed by Gołdyn [82], who analyzed water retention time in three former mill ponds situated on the Cybina River. Average values calculated for intervals 1951-1990 and 1990-1995 were from 0.6 to 3.1 days. Moreover, because in the Middle Ages, water mills were working throughout a year for ca. 100 days (on the average), and they worked ca. 125 days in the 16th century, ca. 150 days in the 19th century, and up to 180 days in the 20th century, it should be assumed that water exchange process was intense only for part of a year, and for the rest it was much less intense (although it was uninterrupted) [2]. As a result, as regards the whole year, it was less repeatable.

\section{Conclusions}

Based on the results of conducted studies on changes of the dynamics and nature of sedimentation in the mill ponds of Struga Rychnowska (Chełmno Lake District, Poland), the following conclusions were drawn:

1. Archival (since 1796) and modern cartographic materials-historical sources containing data on the functioning of water mills-allowed us to determine changes in economic activity in the studied catchment. Thus, it revealed that the patterns in agricultural and forestry land use in 
the Struga Rychnowska drainage basin were insignificant. Agriculture is still dominating at the moraine plateau, while the forest area has increased in the sandr area. All water mills have been closed down.

2. Sediments accumulated in mill ponds (operating in the research area since the 14th century) document changes in the catchment environment during the operation of the mills and after their closing, provided the reservoirs kept the function of water retention. Valuable sources of information about the deposited sediments are their features: granulometric composition, carbonate content, etc.

3. Palinological and ${ }^{14} \mathrm{C}$ analyzes are useful in studying the genesis of mill ponds. It was found, among other things, that mill ponds were placed in natural depressions of the land, usually located above steps occurring in narrowings of the subglacial channel, in which the Struga Rychnowska currently flows. In such cases, the formation of ponds was a restitution of a natural water reservoirs (e.g., the Oleszek reservoir). This was confirmed by the age of the youngest sediments determined by the ${ }^{14} \mathrm{C}$ method ( $530+/-45 \mathrm{cal} \mathrm{BP}-1420 \mathrm{AD}$ ), which were deposited in the disappearing water reservoir at the Oleszek site. It follows that these sediments were formed about 300 years earlier before the waters of the Struga Rychnowska were dammed in this place for the needs of the water mill.

4. Different water retention times indicate different conditions of pond functioning, despite their locations being in the same catchment area.

5. The rate and progress of the process involving basin filling with bottom sediments were affected by: the volume of water mass supplying the ponds and its proportion to total reservoir capacity; morphometric parameters of reservoirs, particularly basin depth and length; location in relation to other elements of hydrographic network directly connected with water mill (e.g., bypass channel); fluctuations of water level in the pond.

Author Contributions: Conceptualization, Z.P.; data curation, Z.P. and D.S.; formal analysis, Z.P. and D.S.; funding acquisition, Z.P. and D.S.; investigation, Z.P. and D.S.; methodology, Z.P. and D.S.; project administration, Z.P. and D.S.; resources, Z.P. and D.S.; validation, Z.P. and D.S.; visualization, Z.P. and D.S.; writing-original draft, Z.P. and D.S.; writing-review and editing, D.S. All authors have read and agreed to the published version of the manuscript.

Funding: The APC was funded by Project Supporting Maintenance of Research Potential of the Department of Physical Edu., Health and Tourism at Kazimierz Wielki University (number. BS/2016/T2) and the Polish Ministry of Science (Project KBN number 6 PO4E 02718 in Nicolaus Copernicus University).

Acknowledgments: The recipients thanked for performing laboratory analyses are-B. Noryskiewicz and K. Lankauf from Nicolaus Copernicus University; and J. Szmanda from the Pedagogical University of Krakow is thanked for help in interpreting sedimentological analyses and earlier cooperation.

Conflicts of Interest: The authors declare no conflict of interest.

\section{References and Notes}

1. Brykała, D. Uwarunkowania przyrodnicze lokalizacji młynów wodnych w zlewni skrwy. In Przemiany Środowiska Przyrodniczego Polski i Jego Funkcjonowanie; German, K., Balon, J., Eds.; IGiGP UJ, PAEK: Kraków, Poland, 2001; pp. 164-171. Available online: https://denali.geo.uj.edu.pl/publikacje,000025?\&page=zakup\& menu=3\&nr=000025_009\&brf=summary//full_text.pdf (accessed on 28 November 2019).

2. Podgórski, Z. Wpływ Budowy i Funkcjonowania Młynów Wodnych na Rzeźbę Terenu i Wody Powierzchniowe Pojezierza Chetmińskiego i Przyległych Części Dolin Wisty i Drwęcy; UMK Toruń: Toruń, Poland, 2004.

3. Kaniecki, A.; Brychcy, D. Średniowieczne Młyny Wodne i Ich Wpływ na Przemiany Ich Zasiegu na Produkcji Zlewni Obry Skwierzyńskiej, Bad; Fizjogr, R.I., Seria, A., Eds.; Geografia Fizyczna: Poznań, Poland, 2010; Volume A61, pp. 145-156. [CrossRef]

4. Fajer, M. Changes in river channel pattern as a result of the construction, operation and decommissioning of watermills-The case of the middle reach of the Liswarta River near Krepice. Environ. Socio-Econ. Stud. 2018, 6, 25-37. [CrossRef] 
5. Fajer, M.; Rzętała, M.A. Mlll pond sediments as the indicator of the environment of the drainage area (an example of Liswarta River, Odra basin, Poland). Environ. Sci. Pollut. Res. 2018, 25, 5832-5847. [CrossRef] [PubMed]

6. Walter, R.C.; Merritts, D.J. Natural streams and the legacy of waterpowered mills. Science 2008, 319, $299-304$. [CrossRef] [PubMed]

7. Schenk, E.R.; Hupp, C.R. Legacy effects of colonial millponds on floodplain sedimentation, bank erosion, and channel morphology, Mid-Atlantic, USA. J. Am. Water Resour. Assoc. 2009, 45, 597-606. [CrossRef]

8. Merritts, D.; Walter, R.; Rahnis, M.; Hartranft, J.; Cox, S.; Gellis, A.; Potter, N.; Hilgartner, W.; Langland, M.; Manion, L.; et al. Anthropocene streams and base-level controls from historic dams in the unglaciated mid-Atlantic region, USA. Phil. Trans. R. Soc. A 2011, 369, 976-1009. [CrossRef]

9. Niemitz, J.; Haynes, C.; Lasher, G. Legacy sediments and historic land use: Chemostratigraphic evidence for excess nutrient and heavy metal sources and remobilization. Geology 2012, 41, 47-50. [CrossRef]

10. James, L.A. Legacy sediment: Definitions and processes of episodically produced anthropogenic sediment. Anthropocene 2013, 2, 16-26. [CrossRef]

11. Wegmann, K.W.; Lewis, R.Q.; Hunt, M.C. Historic mill ponds and piedmont stream water quality: Making the connection near Raleigh, North Carolina. In From the Blue Ridge to the Coastal Plain: Field Excursions in the Southeastern United States; Eppes, M.C., Bartholomew, M.J., Eds.; Geological Society of America Field Guide: Dayton, OH, USA, 2012; Volume 29, pp. 93-121. Available online: https://www.academia.edu/17815197/ (accessed on 28 November 2019).

12. Podgórski, Z.; Zielski, A.; Brykała, D. Vertical-wheeled watermills in Turznice (Poland) in the light of dendrochronological studies. In Book of Abstracts, Proceedings of the XV International Conference of Historical Geographers, Prague, Czechia, 6-10 August 2012; Charles University in Prague, Faculty of Science: Prague, Czech Republic, 2012; pp. 194-195. Available online: https://www.researchgate.net/publication/286620004_FEATURES_OF_THE_PASTORAL_ACTIVITIES_

IN_THE_EUROPEAN_ROMANIC_SPACE_AS_REFLECTED_BY_ANTROPONOMY (accessed on 28 November 2019).

13. Niewiarowski, W. Rozwój i przeobrażenia głównych komponentów środowiska geograficznego mikroregionu osadniczego w okolicach gronowa, woj. toruńskie, w późnym plejstocenie i w holocenie. In Studia Nad Osadnictwem Średniowiecznym Ziemi Chetmińskiej. Gronowski Mikroregion Osadniczy; Olczak, J., Ed.; UMK: Torun, Poland, 1990; pp. 7-26.

14. Fajer, M.; Machowski, R.; Rzętała, M.; Waga, J.M. Relics of frederician colonisation in southern Poland as cultural and natural tourist destinations-The case of the upper Liswarta river catchment. In Proceedings of the 3rd lnternational Multidisciplinary Scientific Conference on Social Sciences and Arts SGEM 2016, Political Sciences, Law, Finance, Economics and Tourism, Albena, Bulgaria, 24-30 August 2016; Book 2. Volume 5, pp. 531-538. Available online: https://www.researchgate.net/publication/308778357// (accessed on 28 November 2019).

15. Foster, I.D.L.; Walling, D.E. Using reservoir deposits to reconstruct changing sediment yields and sources in the catchment of the Old Mill Reservoir, South Devon, U.K., over the past 50 years. Hydrol. Sci. J. 1994, 39, 347-368. [CrossRef]

16. Trimble, S.W. Dating fluvial processes from historical data and artifacts. Catena 1998, 31, 283-304. [CrossRef]

17. Michalska, G.; Szpikowski, J. Akumulacja osadów w stawie młyńskim na parsęcie (storkowo, górna parsęta). In Funkcjonowanie Geosystemów Zlewni Rzecznych, cz. 2, UAM, Zakład Geoekologii i Monitoringu Środowiska Przyrodniczego; Kostrzewski, A., Ed.; Stacja Geoekologiczna w Storkowie: Poznań, Poland, 1999; pp. 131-136. Available online: https://www.researchgate.net/publication/260174862// (accessed on 28 November 2019).

18. Downward, S.; Skinner, K. Working rivers: The geomorphological legacy of English freshwater mills. Area 2005, 37, 138-147. [CrossRef]

19. Pizzuto, J.; O'Neal, M. Increased mid-twentieth century riverbank erosion rates related to the demise, South River, Virginia. Geology 2009, 37, 19-22. [CrossRef]

20. Podgórski, Z. Wpływ budowy młynów wodnych na zmiany krajobrazów pojezierza chełmińskiego. In Krajobraz Kulturowy. Idee, Problemy, Wyzwania, Prace Wydz; Myga-Piatek, U., Ed.; Nauk o Ziemi UŚ: Sosnowiec, Poland, 2001; Volume 12, pp. 117-122. Available online: http://wgsr.uw.edu.pl/wgsr/wp-content/ uploads/2018/11/PodgorskiPIS41.pdf (accessed on 28 November 2019). 
21. Podgórski, Z. Młyny Wodne w Krajobrazie Pojezierza Chełmińskiego. Pr. I Studia Geogr. 2009, 41, $151-161$. Available online: http://wgsr.uw.edu.pl/wgsr/wp-content/uploads/2018/11/PodgorskiPIS41.pdf (accessed on 28 November 2019).

22. Fajer, M. Watermills-A forgotten river valley heritage-Selected examples from the Silesian voivodeship, Poland. Environ. Socio-Econ. Stud. 2014, 2, 1-9. [CrossRef]

23. Brykała, D.; Podgórski, Z.; Sarnowski, Ł.; Lamparski, P.; Kordowski, J. Wykorzystanie energii wiatru i wody w okresie ostatnich 200 lat na obszarze województwa kujawsko-pomorskiego. Pr. Kom. Kraj. Kult. PTG 2015, 29, 9-22.

24. Klimek, K.; Kocel, K.; Łokas, E.; Wachniew, W. Osady denne stawu w dolinie Rudy, dorzecze górnej Odry; Zastosowanie metod kartograficznych i radioizotopowych w określaniu tempa sedymentacji. In Człowiek $w$ Środowisku Przyrod-Niczym-Zapis Działalności; Waga, J.M., Kocel, K., Eds.; PTG Oddział Katowicki: Sosnowiec, Poland, 2003; pp. 74-78.

25. Nascimento, M.R.L.; Mozeto, A.A. Reference values for metals and metalloids concentrations in bottom sediments of Tiete River basin, southeast of Brazil. Contam. Sedyment Contam. 2008, 17, 269-278. [CrossRef]

26. Rendina, A.; Fabrizio de Iorio, A. Heavy metal partitioning in bottom sediments of the Matanza-riachuelo River and main tributary streams. Contam. Sedyment Contam. 2012, 21, 62-81. [CrossRef]

27. Podgórski, Z. Antropogeniczne Zmiany Rzeźby Terenu Województwa Toruńskiego, Studia Societatis Scientiarum Torunensis, Sectio C; TNT UMK: Torun, Poland, 1996; Volume X, p. 4.

28. Podgórski, Z.; Luc, M. Wykorzystanie trójwymiarowej wizualizacji w badaniach wybranych elementów antropogenicznej rzeźby terenu pojezierza chełmińskiego. In Systemy Informacji Geograficznej W Badaniach Środowiska Przyrodniczego, Problemy Ekologii Krajobrazu, T. 4; Kistowski, M., Ed.; Uniwersytet Gdański: Gdańsk, Poland, 1998; pp. 133-138. Available online: http://www.paek.ukw.edu.pl/wydaw/pek.htm (accessed on 28 November 2019).

29. Podgórski, Z. Etapy rozwoju niecki stawu młyńskiego w Oleszku w świetle badań palinologicz-nych. In Konferencja. Roślinność a Procesy Erozji, Transportu i Depozycji, Katedra Paleogeografii i Paleoekologii Czwartorzędu WNoZ UŚ, Komitet Badań Czwartorzędu PAN; Klimek, K., Kocel, K., Eds.; Stowarzyszenie Geomorfologów Polskich: Sosnowiec, Poland, 2002; pp. 123-127.

30. Podgórski, Z.; Szmańda, J. Antropogeniczne Przekształcenia Wybranych Fragmentów rynny Strugi Kowalewskiej Wskutek Budowy i Funkcjonowania Młynów Wodnych; Geografia 32; Acta Universitatis Nikolai Copernici: Torun, Poland, 2002; Volume 109, pp. 111-125.

31. Podgórski, Z.; Szmańda, J. Parametry uziarnienia osadów małych zbiorników zaporowych pojezierza chełmińskiego na tle osadów wybranych środowisk sedymentacyjnych. In Dokumentacja Geograficzna; Nr 31; IGiPZ PAN: Warszawa, Poland, 2004; pp. 101-103. Available online: http://www.rcin.org.pl/Content/6264/ WA51_16111_r2004-nr31_Dokomentacja-Geogr.pdf (accessed on 28 November 2019).

32. Mendyk, Ł.; Sykuła, M. Spatial Variability of Actual Soil Moisture, pH and Bulk Soil Electrical Conductivity within the Area of the Former Oleszek Mill Pond Basin. Pol. J. Soil Sci. 2014, CLVII/1, 17-25. Available online: https://journals.umcs.pl/pjss/article/view/219/217 (accessed on 28 November 2019). [CrossRef]

33. Donovan, M.; Miller, A.; Baker, M. Reassessing the role of milldams in Piedmont floodplain development and remobilization. Geomorphology 2016, 268, 133-145. [CrossRef]

34. Kaiser, K.; Keller, N.; Brande, A.; Dalitz, S.; Hensel, N.; Heußner, K.U.; Kappler, C.; Michas, U.; Müller, J.; Schwalbe, G.; et al. A large-scale medieval dam-lake cascade in central Europe: Water level dynamics of the Havel River, Berlin-Brandenburg region, Germany. Geoarchaeology 2018, 33, 237-259. [CrossRef]

35. Maaß, A.L.; Schüttrumpf, H. Elevated floodplains and net channel incision as a result of the construction and removal of water mills. Geogr. Ann. Ser. Aphysical Geogr. 2019, 101, 157-176. [CrossRef]

36. Brykała, D. Rekonstrukcja retencji zbiornikowej zlewni Skrwy Lewej w ciagu ostatnich 200 lat. Przeglad Geogr. 2005, 77, 69-89.

37. Niewiarowski, W. Mapa Geomorfologiczna Polski 1: 50 000, ark Torun: Warszawa; Institute of Geography and Spatial Organization Polish Academy of Sciences: Warsaw, Poland, 1958.

38. Niewiarowski, W. Mapa Geomorfologiczna Polski, 1:50 000, ark Toruń: Kowalewo; Institute of Geography and Spatial Organization Polish Academy of Sciences: Warszawa, Poland, 1965.

39. Topographic map 1:10000, ark.233.233-Rogówko; Państwowe Przedsiębiorstwo Geodezyjno-Kartograficzne (Zjednoczenie Przedsiębiorstw Geodezyjno-Kartograficznych “GEOKART”): Rzeszów, Poland, 1991. 
40. Map of the Polish Hydrographic Division; Department of Hydrography and Morphology of River Channels Institute of Meteorology and Water Management. Available online: http://mapa.kzgw.gov.pl/ (accessed on 10 December 2016).

41. Digital Elevation Model Data; Institute of Geodesy and Cartography. Available online: http://geoportal.gov. $\mathrm{pl} / /$ (accessed on 31 January 2013).

42. Archiwum Państwowe w Toruniu [State Archives in Torun], no. 650, vol. 496: Borówno-plan wsi, 1798, skala 190 Prętów Reńskich-14,2 cm; 651/T. 310: Borówno-Plan wsi, 1824, skala 240 Prętów Reńskich-18 cm; 700/T. 274: Gronowo-Kanał Odwadniajacy, 1826, skala 190 Prętów Pruskich-14,2 cm; 792/T. 474: Plan Młyna Oleszek, 1802, skala 150 Prętów Reńskich-11,2 cm; Archiwum Państwowe w Toruniu: Toruń, Poland.

43. Reichsamt für Landesaufname ... und Königl. Preuss. Landesaufname ... ; die Karte (Maßstab 1:25 000) Blatt: 1438 (2878)-Kielbasin, 1910; 1512-Preuß. Lanke, 1911; 2978-Gramtschen, 1910 (zbiory UMK w Toruniu).

44. Topographische Karte (Maßstab 1:25 000); Sect.: 1267-Jablonowo, 1873; 1431-Kielbaszin, 1873; 1511-Gremboczin, 1873 (zbiory Staatsbibliothek zu Berlin).

45. Wiebe, X. Nivellement des Entwäasserungsgrabens für die Adlich Gronower Wiesen und des Oleszker Mühlteiches ... ; Archiwum Państwowe: Torun, Poland, 1826; nr 700, teka 274.

46. Zimmermann, J. Bruillon Plan von dem Thorner Eignthums Dorff Boruwno ... ; Archiwum Państwowe w Toruniu [State Archives in Torun]: Toruń, Poland, 1802; Volume 496, no. 650.

47. Mrózek, W. Wody płynące. In Województwo Toruńskie. Przyroda-Ludność i Osadnictwo-Gospodarka; Galon, R., Ed.; PWN: Warszawa, Poland; Poznań, Poland; Toruń, Poland, 1984; pp. 110-139.

48. Polish Hydrographic Division. Part I: Numerically-Descriptive Statement; Institute of Meteorology and Water Management: Warszawa, Poland, 1983; p. 924.

49. Dynowska, I. Typy Reżimów Rzecznych w Polsce, Zeszyty Naukowe Uniwersytetu Jagiellońskiego, Prace Geograficzne, z. 28, Kraków, 151 s. 1972. Available online: http://rcin.org.pl/Content/28024/WA51_40060_ r1972-z6_Dokumentacja-Geogr1.pdf (accessed on 28 November 2019).

50. Pekarova, P.; Miklanek, P.; Pekar, J. Long-term trends and runoff fluctuations of European rivers. Climate Variability and change-hydrological Impacts. In Proceedings of the Fifth FRIEND World Conference, Havana, Cuba, 27 November-2 December 2006; IAHS Publication: Montevideo, Uruguay, 2006; Volume 308, pp. 520-525. Available online: https://iahs.info/uploads/dms/13714.94-520-525-97-308-Pekarova.pdf (accessed on 22 December 2019).

51. Studium Gospodarki Wodnej i Retencji Woj. Toruńskiego; Office of Water Project and Melioration: Toruń, Poland, 1981.

52. Preussisches Urkundenbuch, t. 1-4, 1882-1958, Königsberg-Marburg, 2/1, no. 334. Available online: http://opac.regesta-imperii.de/lang_de/anzeige.php?pk=10159 (accessed on 28 November 2019).

53. Karte des Deutschen Reiches, die Karte (Maßstab 1:100 000) Großblatt: 57-Thorn, 1924 oder 1930. Available online: https://www.landkartenarchiv.de/deutschland_kartedesdeutschenreiches.php (accessed on 28 November 2019).

54. Schroetter, F. 1803, Karte von Ostpreussen nebst Preussisch Lithauen und Westpreussen nebst dem Netzdistrict (1796-1802), atlas, skala 1: Ca.150 000), Berlin, Sect. XXI. Available online: https://rcin.org.pl/dlibra/ publication/12308 (accessed on 28 November 2019).

55. Topographic map 1:1000000, ark.36-27-Toruń; Wojskowy Instytut Geograficzny: Toruń, Poland.

56. Topographic map 1:50000, ark.35-27-Grudziadz-A, ark. 36-27-Toruń-B; Sztab Generalny Wojska Polskiego: Warszawa, Poland, 1948.

57. Porębska, K. Słownik Historyczno-Geograficzny Ziemi Chetmińskiej w Średniowieczu; Wyd. PAN: Wrocław, Poland; Warszawa, Poland; Kraków, Poland; Gdańsk, Poland, 1971; Available online: http://www.slownik. ihpan.edu.pl// (accessed on 28 November 2019).

58. Sulimierski, F.; Chlebowski, B.; Walewski, W. Słownik Geograficzny Królestwa Polskiego i Innych Krajów Słowiańskich, t. I-1880, t. III-1882, t. IV-1883, t. VI-1885, t. VII-1886, t. XI-1890, Warszawa. Available online: http://dir.icm.edu.pl/pl/Slownik_geograficzny/Tom_XI// (accessed on 28 November 2019).

59. Arnold, S. Słownik Geograficzny Państwa Polskiego i Ziem Historycznie z Polską Związanych, t. 1: Pomorze Polskie. Pomorze Zachodnie. Prusy Wschodnie, Wyd. Pol. Tow. Krajozn, 1936, Warszawa. Available online: https://fbc.pionier.net.pl/details/oai:www.wbc.poznan.pl:30537 (accessed on 28 November 2019).

60. PN-ISO 11277:2005, Soil Quality—Determination of the Particle Size Distribution in Mineral Soil Material—Method by Sieving and Sedimentation, KT 192; Polish Committee for Standardization: Warsaw, Poland. 
61. ISO 13320:2009, Particle Size Analysis—Laser Diffraction Methods, ISO/TC 24/SC 4, Particle Characterization. Available online: https://www.sis.se/api/document/preview/911506/ (accessed on 29 November 2019).

62. Instrukcja w sprawie opracowania i wydania Szczegółowej Mapy Geologicznej Polski w skali 1:50 000, wydanej na podstawie zarządzenia Prezesa Centralnego Urzędu Geologicznego z dnia 21 października 1975 r. dla osadów piaszczysto-mułkowo-ilastych (CUGIG 1975), Wyd. Geol., Warszawa.

63. Bengtsson, L.; Enell, M. Chemical analysis. In Handbook of Holocene Palaeoecology and Palaeohydrology; Berglund, B.E., Ed.; John Wiley \& Sons Ltd.: Chichester, UK, 1986; pp. 423-451.

64. Januszkiewicz, T. Studia nad metodą analizy chemicznej składu współczesnych osadów dennych jezior. Zesz. Nauk. 1978, 8, 3-29.

65. Rzepecki, P. Klasyfikacja i główne typy litologiczne osadów jeziornych. Zesz. Nauk. AGH, Geologia 1983, 9, 73-94.

66. Folk, R.L.; Ward, W.C. Brazos river bar, a study in the significance of grain size parameters. J. Sed. Pertol. 1957, 27, 3-26. [CrossRef]

67. Passega, R. Grain-size representation by CM patterns as a geological tool. J. Sed. Petrol. 1964, 34, 830-847. Available online: http://citeseerx.ist.psu.edu/viewdoc/download?doi=10.1.1.890.8534\&rep=rep1\&type=pdf (accessed on 29 November 2019). [CrossRef]

68. Passega, R.; Byramjee, R. Grain size image of clastic deposits. Sedimentology 1969, 13, 830-847. [CrossRef]

69. Kalib14C. Available online: https://www.adamwalanus.pl/c14cal.html (accessed on 2 December 2019).

70. Berglund, B.F.; Ralska-Jasiewiczowa, M. Pollen analysis and pollen diagrams. In Handbook of Holocene Palaeoecology and Palaeohydrology; Berglund, B.E., Ed.; John Wi-ley \& Sons Ltd.: Chichester, UK, 1986; pp. 455-484.

71. Erdtman, G. An Introduction to Pollen Analysis; Read Books Ltd.: Waltham, MA, USA, 1953.

72. Starmach, K. Hydrobiologiczne podstawy użytkowania przez wodociagi płytkich zbiorników rzecznych. Pol. Archiw. Hydrob. 1958, 4, 10-67.

73. Lech, A. Uboczna produkcja młynarska w XVII-XIX w. In Studia z Dziejów Gospodarstwa Wiejskiego; t. 12, z. 1; IHKM PAN, PWN: Warszawa, Poland, 1970; pp. 181-202.

74. Małyszycki, S. Młynarstwo Zbożowe, t. 1, Warszawa, 359 s. 1890. Available online: https://rcin.org.pl/dlibra/ show-content/publication/edition/5670?id=5670 (accessed on 8 December 2019).

75. Zając, K. Polska Czerwona Księga Zwierząt: Anodonta cygnea (Linnaeus, 1758). Instytut Ochrony Przyrody PAN. 2011. Available online: http://www.iop.krakow.pl/pckz/opis8ec2.html?id=128\&je=pl (accessed on 8 December 2019).

76. Celmer, T.; Marciniak, K.; Wójcik, G. Wody powierzchniowe i podziemne. In Zintegrowany Monitoring Środowiska Przyrodniczego-Stacja Bazowa w Koniczynce; Wójcik, G., Marciniak, I.K., Eds.; Biblioteka Monitoringu Środowiska: Warszawa, Poland; Torun, Poland, 1996; pp. 77-89.

77. Sundborg, A. The River Klarälven, a study of fluvial processes. Geogr. Ann. 1956, 38, 127-316. [CrossRef]

78. Sundborg, A. Some aspects on fluvial sediments and fluvial morphology. Geogr. Ann. 1967-1968, 49-50. [CrossRef]

79. Łajczak, A. Studium Nad Zamulaniem Wybranych Zbiorników Zaporowych w Dorzeczy Wisty; Monografie Komitetu Gospodarki Wodnej PAN nr 8; Oficyna Wydawnicza Politechniki Warszawskiej: Warszawa, Poland, 1995; p. 108.

80. Cyberski, J. Zjawiska akumulacyjno-erozyjne w rzekach objętych działaniem budowli piętrzacych. Czas. Geogr. 1984, 55, 355-363.

81. Jespersen, A. Trough or pentrough Regional Preference or Historical Development. In Proceedings of the Transactions of the Fifth Symposium The International Molinological Society (TIMS), Paris, France, 5-10 April 1982; pp. 229-247.

82. Gołdyn, R. Zmiany Biologicznych i Fizyczno-Chemicznych Cech Jakości Wody Rzecznej Pod Wpływem Jej Piętrzenia We Wstępnych, Nizinnych Zbiornikach Zaporowych; Wydawnictwo Naukowe UAM: Poznań, Poland, 2000; p. 185.

(C) 2020 by the authors. Licensee MDPI, Basel, Switzerland. This article is an open access article distributed under the terms and conditions of the Creative Commons Attribution (CC BY) license (http://creativecommons.org/licenses/by/4.0/). 